\title{
Medievalista
}

Online

$20 \mid 2016$

Número 20

\section{Ecos de um Eco maior}

\section{Redacção}

\section{OpenEdition}

Journals

Edição electrónica

URL: http://journals.openedition.org/medievalista/1165

DOI: 10.4000/medievalista. 1165

ISSN: 1646-740X

\section{Editora}

Instituto de Estudos Medievais - FCSH-UNL

Refêrencia eletrónica

Redacção, «Ecos de um Eco maior », Medievalista [Online], 20 | 2016, posto online no dia 01 dezembro 2016, consultado o 23 setembro 2020. URL : http://journals.openedition.org/medievalista/1165 ; DOI : https://doi.org/10.4000/medievalista. 1165

\section{(c) () (8)}

Mediavalista está licenciado com uma Licença Creative Commons - Atribuição-NãoComercial 4.0 Internacional. 
Revista ISSN 1646-740X

Título / Title: ECOS DE UM ECO MAIOR

Autor(es) / Author(s): Redacção

Universidade / University: Universidade Nova de Lisboa

Faculdade e Departamento / Unidade de Investigação - Faculty and Department /

Research Center: Instituto de Estudos Medievais, Faculdade de Ciências Sociais e

Humanas da Universidade de Lisboa

Código Postal / Postcode: 1069-061

Cidade / City: Lisboa

País / Country: Portugal

Email: medievalista@fcsh.unl.pt

Fonte: Medievalista [Em linha]. Direc. Bernardo Vasconcelos e Sousa. Lisboa: IEM.

Disponível em:

http://www2.fcsh.unl.pt/iem/medievalista/MEDIEVALISTA20/editorial2001.html

ISSN: 1646-740X 


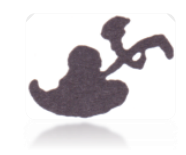

\section{ECOS DE UM ECO MAIOR}

\section{A Redacção}

No passado dia 19 de Fevereiro morreu em Milão Umberto Eco, com 84 anos. Figura de referência na cultura contemporânea, Eco incarnou o espírito e a acção do intelectualsocial do século XX. Reconhecido e respeitado pela sua vastíssima erudição, desde a sua tese de doutoramento sobre São Tomás de Aquino até aos estudos na área da Semiótica, da Filosofia ou da Estética, nunca deixou de estar atento aos fenómenos da "cultura de massas" que marcam os nossos dias. Foi assim com a banda desenhada ou com o impacto dos media, e particularmente da televisão, sem esquecer o "império" da Internet, face ao qual o seu espírito crítico se manifestou por vezes de forma impiedosa. Ficaram célebres, por exemplo, as acutilantes considerações acerca dos efeitos da Internet e das redes sociais na "imbecialização" dos incautos.

Figura mediática por excelência e à escala global, Umberto Eco nunca se fez rogado na utilização de tal estatuto para dar voz às suas opiniões em matérias culturais, mas também sociais e políticas. Poucos meses antes da sua morte, numa entrevista ao semanário português Expresso, falava desassombradamente, em nome de princípios humanistas e solidários, sobre as ondas de refugiados que demandavam uma Europa insensível e desarticulada.

O saber e o rigor de Eco não eram inimigos do humor e da ironia. O cruzamento da mais densa temática filosófica da Idade Média com a estrutura do livro policial, como ocorre por exemplo n' O Nome da Rosa, sem dúvida o romance que mais o celebrizou, confere um lado lúdico à sua obra ficcional. Mas até num livrinho à partida de assunto árido e desinteressante, como o célebre Como se Faz uma Tese em Ciências Humanas, cuja edição original italiana é de 1977 e que na sua tradução portuguesa de 1980 teve uma enorme influência na formação de sucessivas gerações de estudantes universitários na área das Ciências Sociais e das Humanidades no nosso país, o Autor consegue explicar de forma desempoeirada, concreta e prática os cânones do ofício, abordando 
questões tão prosaicas como as notas de rodapé, a elaboração de um plano-índice ou a apresentação da bibliografia num trabalho académico.

A obra que dirigiu em quatro volumes, sobre A Idade Média, editada entre nós pela Dom Quixote, revela-nos a sensibilidade polifacetada de um Umberto Eco atento às mais recentes tendências da investigação. E não por uma questão de moda, mas pelo estimulante desejo de tudo relacionar, pela quase ânsia de tudo perceber, desde as estruturas materiais às formas do pensamento, da arte e da religiosidade, desde a viagem por espaços físicos ao imaginário das utopias.

No seu testamento, Eco pediu aos colegas e a todos os que lhe eram próximos para não promoverem, autorizarem ou participarem em colóquios ou outros eventos públicos de qualquer espécie sobre a sua personalidade e a sua obra durante os dez anos que se seguirão à sua morte. Os mais afoitos na apropriação dos legados alheios tiveram e terão, pois, de se conter. Umberto Eco vale pelo que disse, escreveu e fez, muito mais do que pelo que dele se possa dizer. E se aqui o evocamos é pelo que lhe devemos, não pelo que nos possa render.

Este número da Medievalista OnLine apresenta como "Destaque" a conferência de Arsenio Dacosta, intitulada "Geografías imperfectas: linaje y poder en la obra de Luís Krus", proferida no colóquio realizado em Lisboa em Outubro de 2015, na passagem dos 10 anos sobre a morte do fundador do Instituto de Estudos Medievais e primeiro Director da nossa revista. Segue-se um conjunto de cinco "Artigos" de temática variada: da autoria de Jean-Pierre Molénat, um texto sobre os documentos árabes cristãos de Toledo nos séculos XII e XIII; de Luísa Trindade, sobre uma representação da Rua Nova dos Mercadores, em Lisboa; de Maria Amélia Álvaro de Campos, sobre a fundação de uma capela em Coimbra; de Pablo Castro Hernández, sobre monstros e prodígios; e de Natália Albino Pires, sobre a imagem do "outro" na Crónica da Tomada de Ceuta. Inclui-se a habitual secção de "Recensões", com análises de António Martins Costa ao mais recente livro de Ângela Beirante, e de Paulo Almeida Fernandes sobre o trabalho de Artur Rocha acerca da muralha dionisina de Lisboa. Refira-se ainda a apresentação da tese de doutoramento de Joaquim Bastos Serra e, na secção "Varia", uma evocação do medievalista francês Jean Favier, da autoria de Armando Luís de Carvalho Homem. 
Sem querermos pôr-nos em bicos de pés, estes são, à nossa medida, ecos de um Eco maior. Pelo que aqui fica dito e pelo que não cabe dizer, na Medievalista consideramos Umberto Eco como um daqueles gigantes a cujos ombros queremos subir para podermos enxergar mais além. Para vermos de modo mais nítido os longínquos tempos medievais, é certo. Mas também para entendermos melhor o nosso próprio tempo. Como Umberto Eco não se cansou de fazer.

\section{COMO CITAR ESTE ARTIGO}

\section{Referência electrónica:}

"ECOS DE UM ECO MAIOR”. Medievalista [Em linha]. N. 20 (Julho - Dezembro 2016). [Consultado dd.mm.aaaa]. Disponível em http://www2.fcsh.unl.pt/iem/medievalista/MEDIEVALISTA20/editorial2001.html ISSN 1646-740X.

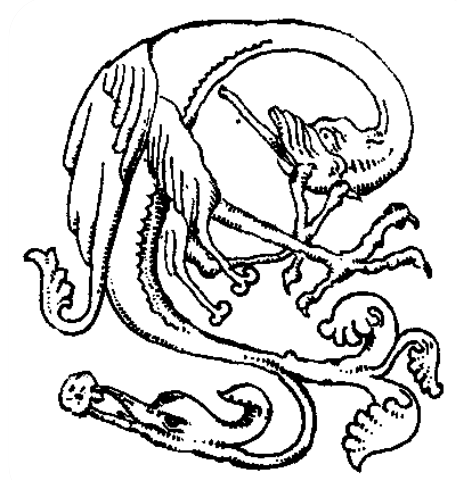

